Dokuz Eylül Üniversitesi-Mühendislik Fakültesi Fen ve Mühendislik Dergisi

Cilt 20, Sayı 59, Mayıs, 2018
Dokuz Eylul University-Faculty of Engineering Journal of Science and Engineering Volume 20, Issue 59, May, 2018

DOI: $10.21205 /$ deufmd. 2018205936

\title{
Electrochemical Vanillin Determination on Gold Nanoparticles Modified Multiwalled Carbon Nanotube Electrode
}

\section{Çağrı Ceylan KOÇAK ${ }^{* 1}$, Şükriye KARABiBBEROĞLU²}

${ }^{1}$ Dokuz Eylül University, Bergama Vocational School, 35700, İzmir (ORCID: 00000001-9928-8806)

${ }^{2}$ Ege University, Faculty of Science, Chemistry Department, 35040, İzmir(ORCID: 0000-0003-3360-6765)

(Alınış / Received: 25.05.2017, Kabul / Accepted: 19.01.2018, Online Yayınlanma / Published Online: 15.05.2018)

Keywords

Vanillin,

Nanoparticles, Carbon Nanotube.

Abstract: In this study, modified electrodes were prepared for Vanilline (VAN) determination. Multiwalled carbon nanotubes (MWCNT) were functionalized with acid treatment and then gold nanoparticles were electrodeposited on the MWCNTs by applying several repetitive scans in order to form gold nanoparticles modified multiwalled carbon nanotube glassy carbon electrode (Au-MWCNT/GCE) surface. The morphology and structure of electrode surfaces were characterized by scanning electron microscopy (SEM). The resulting Au-MWCNT/GC electrode showed efficient behavior to VAN electro-oxidation. The calibration graph consisted of two linear segments of $7.0 \times 10^{-8}$ $6.5 \times 10^{-6} \mathrm{~mol} \mathrm{~L}^{-1}$ and $7.0 \times 10^{-6}-7.5 \times 10^{-5} \mathrm{~mol} \mathrm{~L}^{-1}$ with a detection limit of $3.8 \times 10^{-8} \mathrm{~mol} \mathrm{~L}^{-1}$ that obtained from differential pulse studies. The practical applicability of the proposed modified electrode was tested for the determination of VAN in commercial ice cream and milk powder. The satisfactory results show that the $\mathrm{Au}-\mathrm{MWCNT} / \mathrm{GCE}$ has promising potential in sensor applications.

\section{Altın Nanoparçacık Modifiye Çok Duvarlı Karbon Nanotüp Elektrotlarda Vanilin Tayini}

\begin{tabular}{l}
\hline Anahtar \\
Kelimeler \\
Vanilin, \\
Nano Parçacıklar, \\
Karbon Nanotüp.
\end{tabular}

Özet: Bu çalıșmada, Vanilin(VAN) tayini için modifiye elektrotlar hazırlanmıştır. Çok duvarlı karbon nanotüpler (MWCNT) asit muamelesi ile foksiyonalize edilmiş ve ardından altın nanoparçacıklar ardışık tekrarlanan taramalar ile altın nanoparçacık modifiye çok duvarlı karbon nanotüp camımsı karbon elektrot (Au-MWCNT/GCE) olușturmak üzere elektrokimyasal olarak biriktirilmiştir. Elektrot yüzey yapısı ve morfolojisi taramalı electron mikroskopu (SEM) ile karakterize edilmiștir. Elde edilen Au-MWCNT/GC elektrot VAN'nin yükseltgenmesine iyi bir yanıt vermiștir. Diferansiyel puls çalışmalarından elde edilen kalibrasyon eğrisi iki doğrusal aralık içerir ve bu aralıklar $7.0 \times 10^{-8}-6.5 \times 10^{-6} \mathrm{~mol} \mathrm{~L}^{-1}$ ve $7.0 \times 10^{-6}-7.5 \times 10^{-5}$ 
mol L ${ }^{-1}$ dir ve belirtme alt sınırı ise $3.8 \times 10^{-8} \mathrm{~mol} \mathrm{~L}^{-1}$ dir. Önerilen modifiye elektrodun pratik uygulaması ticari dondurma ve süt tozundaki VAN tayini ile test edimiştir. Tatmin edici sonuçlar, $\mathrm{Au}-$ MWCNT/GCE nin sensör uygulamaları için umut vadeden potansiyele sahip olduğunu göstermiştir.

${ }^{*}$ Corresponding Author: Çağrı Ceylan KOÇAK: ceylan.kocak@deu.edu.tr

\section{Introduction}

Vanillin $\quad\left(\mathrm{C}_{8} \mathrm{H}_{8} \mathrm{O}_{3}\right)$, (4-hydroxy-3methoxybenzaldehyde) is a phenolic aldehyde derived from vanilla bean e bean or pod of the tropical Vanilla plant that contains Vitamin-B, potassium, calcium, thiamin, riboflavin, and iron $[1$, 2].

Vanillin has been acting as an indispensable smell additive in most of the beverages and desserts such as candies, biscuits, cakes, pudding, chocolate, ice creams, wine which attract a large number of people, especially in the young ages $[3,4]$. The overtaking of VAN can cause some undesirable effects to their consumers. The high dose of VAN can lead to severe side effects, including headaches, emesis, dyspnea, nausea and vomiting, and could damage liver and kidney functions $[5,6]$. Due to the side effects of vanillin, it is forbidden in the infant food. Therefore, the quantitative determination of vanillin in foods and beverages has significant importance, especially for growing children [7].

Vanillin has been determined by various techniques such as; liquid chromatography-quadrupole linear ion trap mass spectrometry [8], capillary electrophoresis $\quad[9, \quad 10]$, chemiluminescence $\quad[11, \quad 12]$, chromatography [13-15] etc. These methods generally need multistep pretreatments which are timeconsuming and also expensive. Among all, voltammetric techniques are suitable alternatives for determination of various organic and inorganic compounds due to their several advantages which are rapid, simple, cheap, portable instrumentation, sensitive and selective [16-18]. Despite the advantages of electrochemical techniques, some limitations still need to be overcome such as high oxidation potentials and electrode fouling at conventional electrodes [19-21].

Metal nanoparticles have been extensively used as an electrode modifier in electrochemical studies due to their higher electron transfer rate, catalytic activity, and increased electrode surface area compared to the other conventional electrodes [22-25]. Besides their advantages, metal nanoparticles need a supporting material for stability on electrode surface in solutions. Carbon nanotubes (CNTs) are great substrates for this purpose. They possess many special properties, such as high chemical stability, surface area, enhanced mass transport capability and good electrical conductivity [26-29].

In this study, electrochemically synthesized gold nanoparticles modified on multiwall carbon nanotubes in order to prepare a sensitive electrochemical sensor for VAN determination. This modified electrode was successively applied to real sample detection of food products.

\section{Experimental Study}

\subsection{Materials and Method}

Multi-walled carbon nanotubes (MWCNTs, purity > 95\% diameter 110 $170 \mathrm{~nm}$, length $9 \mathrm{~lm}$ ) were purchased from Aldrich. N,N Dimethyl Formamide (DMF), $\mathrm{HNO}_{3}$ and $\mathrm{HCl}$ were all in ultrapure grade, purchased from Merck. 
$\mathrm{Au}$ solution was obtained by dissolving $\mathrm{Au}$ wire $(99.999 \%$ in purity, Tanaka Kikinzoku Kogyo Co., Ltd.). All solutions were prepared using ultrapure water (Milli-Q 18.2 MX cm, Millipore System Inc.).

Voltammetric measurements were carried out by using a BAS 100B/W voltammetric analyzer (Bioanalytical Systems, Inc.) with a three electrode system consisting of a working electrode (bare GCE with a diameter of $3 \mathrm{~mm}$, $0.0707 \mathrm{~cm}^{2}$ geometric area, MWCNT/GCE and $\mathrm{Au}-\mathrm{MWCNT} / \mathrm{GCE}$ ), a platinum wire counter electrode, and an $\mathrm{Ag} / \mathrm{AgCl}$ (sat. $\mathrm{KCl})$ reference electrode. The $\mathrm{pH}$ measurements were made with a WTW handheld 330i ion analyzer meter. The surface morphology of the modified electrode was examined using a Philips XL 30 SFEG scanning electron microscopy.

\subsection{Preparation of Modified Electrodes}

Before modification, GCE was activated by polishing with a different grade of $\mathrm{Al}_{2} \mathrm{O}_{3}$ slurry $(0.05-3 \mu \mathrm{m})$ on a synthetic cloth, then rinsing with pure water and ultrasonication for $3 \mathrm{~min}$ in an ultrapure water and ethanol mixture.

Multiwall carbon nanotube, as received, was pretreated with concentrated $\mathrm{HNO}_{3}$ for purification and activation of nanotubes as follows: appropriate amount of MWCNT was boiled in concentrated $\mathrm{HNO}_{3}$ for few minutes and then washed several times with ultrapure water. The acid-treated MWCNT was dispersed in DMF to get a black suspension. A $10 \mu \mathrm{L}$ sample of MWCNT suspension was dropped on the pre-conditioned bare GCE surface and then the DMF of the suspension on the GCE surface was evaporated at $60^{\circ} \mathrm{C}$ for one hour to fabricate the MWCNT/GCE.
The electrochemical $\mathrm{Au}$ nanoparticles deposition was performed by using the electrochemical reduction of $1 \mathrm{mmol} \mathrm{L}^{-1}$ $\mathrm{HAuCl}_{4}$ on the MWCNT/GCE in $0.1 \mathrm{~mol} \mathrm{~L}$ $1 \mathrm{HCl}$ solution. It was performed by consecutive cyclic voltammograms in the potential range between $-1.0 \mathrm{~V}$ and $0.6 \mathrm{~V}$.

\section{Results}

\subsection{Characterization of Electrodes}

Figure 1. shows the SEM micrographs of modified electrodes. The SEM image of acid-treated MWCNT (Figure 1.a) revealed that the distribution of carbon nanotubes on the GCE surface was rather uniform with a smooth surface. Figure 1.b shows that there was nano $\mathrm{Au}$ formation as bright, round-shaped, homogeneously dispersed particles adhering to the MWCNT/GC electrode surface. In the backscattered image, due to higher molecular weight of $\mathrm{Au}, \mathrm{Au}$ nanoparticles were seen bright. The average particle size of $\mathrm{Au}$ on MWCNT/GCE was calculated as $200 \mathrm{~nm}$. In Figure 1.c energy dispersive X-ray spectroscopy (EDX) measurements confirmed that $\mathrm{Au}$ nanoparticles were successfully electrodeposited on MWCNT/GCE. The weight gain of the MWCNTs due to the Au loading was about $4.81 \%$. 


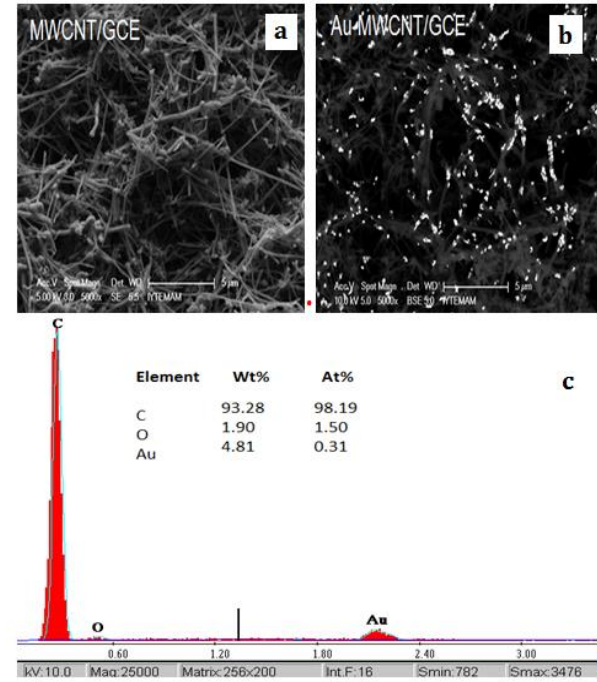

Figure 1. SEM images of a) MWCNT/GCE, b) $\mathrm{Au}-\mathrm{MWCNT} / \mathrm{GCE}, \mathrm{c}$ ) EDX spectrum of $\mathrm{Au}-$ MWCNT/GCE.

\subsection{Electrochemical Behavior of Vanillin}

The electrochemical behavior of VAN was investigated by cyclic voltammetric technique with bare and modified electrodes. Figure 2 showed the comparison of bare GCE, MWCNT/GCE and Au-MWCNT/GCE towards VAN oxidation in PBS. A small and broad oxidation peak was observed for $10^{-4} \mathrm{~mol}$ $\mathrm{L}^{-1}$ vanillin at $0.056 \mathrm{~V}$ on the bare GCE surface. After MWCNT deposition, the peak current shifted to the more negative values with increasing current value. The best catalytic activity in terms of peak current and peak potential was observed at Au-MWCNT/GC electrode. The peak current was found 14 times higher than bare electrode. In addition, VAN was oxidized at more negative potentials ( 40 $\mathrm{mV}$ ) as compared to the GCE. This improved characteristic can be attributed to the synergistic effect of both gold nanoparticles and carbon nanotubes.

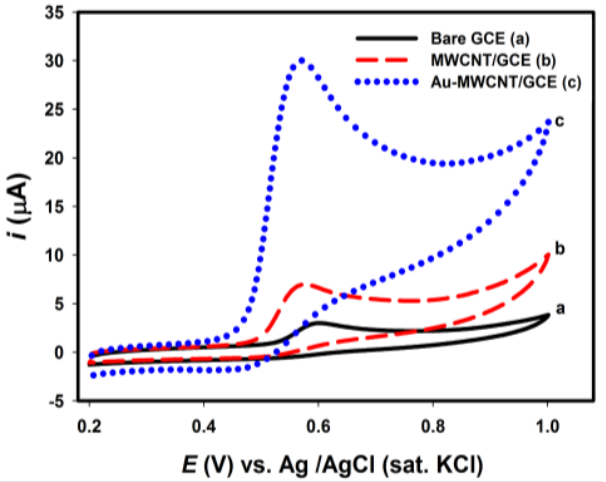

Figure 2. Cyclic voltammograms of $10^{-4} \mathrm{~mol}$ $\mathrm{L}^{-1}$ Vanillin oxidation on a) Bare GCE (and inset), b) MWCNT/GCE and c) AuMWCNT/GCE

The effect of electrolyte solution $\mathrm{pH}$ on the electrochemistry of VAN oxidation was studied in the PBS with the $\mathrm{pH}$ range 2.0-8.0 (figure not shown). The dependence of peak potential on solution $\mathrm{pH}$ was represented in Figure 3a. The peak potential of VAN shifted to more negative potential values with increasing $\mathrm{pH}$ values which proved that protons were directly involved in the VAN electro-oxidation. The peak potential linearly depends on $\mathrm{pH}$ in the range of 2.0-8.0 according to following equation: Ep $(\mathrm{V})=-0.06 \mathrm{pH}+1.0272$ with $\mathrm{R}^{2}=$ 0.9956. The slope of $-60.0 \mathrm{mV} \mathrm{pH}^{-1}$ indicates that the electron transfer is accompanied by an equal number of protons and electrons in the electrochemical oxidation reaction of VAN on Au-MWCNT/GCE. The high oxidation peak current at relatively negative potentials was obtained at pH:7.15 PBS that chosen as an optimum $\mathrm{pH}$ for further studies.

The gold nanoparticles modified MWCNT/GC electrodes were prepared with different coverage by changing the cycle numbers to obtain the most appropriate surface for VAN oxidation. Cycle numbers varies between 1 and 20 that carried out in $1 \mathrm{mmol} \mathrm{L}^{-1} \mathrm{HAuCl}_{4}$ containing $0.1 \mathrm{~mol} \mathrm{~L}^{-1} \mathrm{HCl}$ solution. 5 successive cycles of gold deposition on 
the MWCNT/GCE surface, provide the desirable change in peak characteristics in terms of peak current (Figure $3 b$ ).

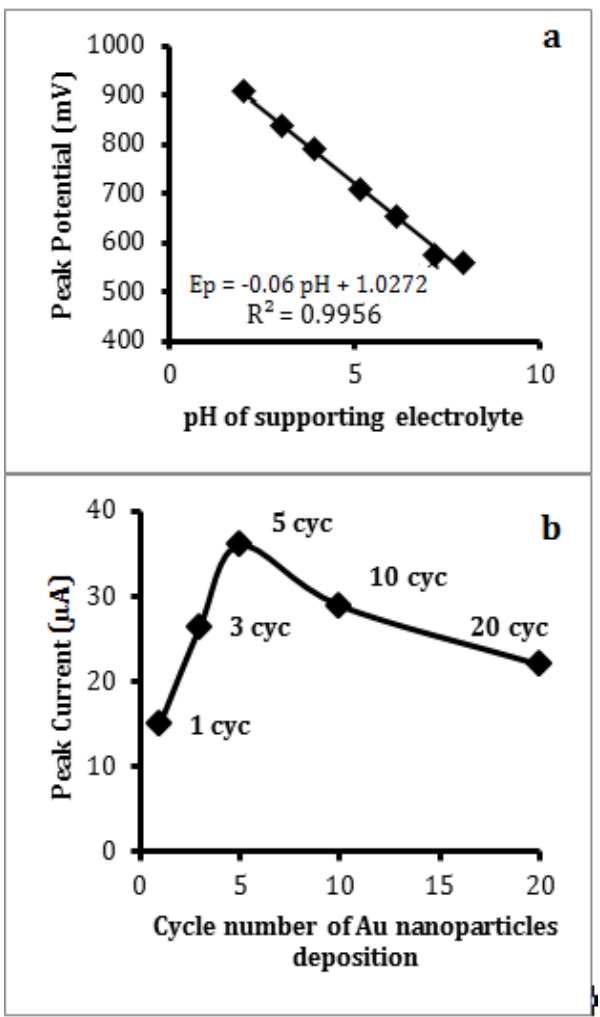

Figure 3. Influence of the $\mathrm{pH}$ of supporting electolyte on the peak potential of VAN oxidation at MWCNT/GCE and b) Effect of the cycle number of $\mathrm{Au}$ deposition on MWCNT/GCE on oxidation peak of $10^{-4} \mathrm{M}$ VAN in pH 7.15 PBS.

In Figure 4, the effect of scan rate on peak current of vanillin oxidation was also determined in VAN containing PBS. The oxidation peak current of VAN at AuMWCNT/GCE was proportional to the square root of the scan rate in the range of $10-200 \mathrm{mV} \mathrm{s}^{-1}$ which suggests a diffusion-controlled electrode process takes place on the electrode surface. The oxidation peak potential of VAN was shifted positive values with increasing the scan rate that the electron transfer was quasi-reversible (not shown here).

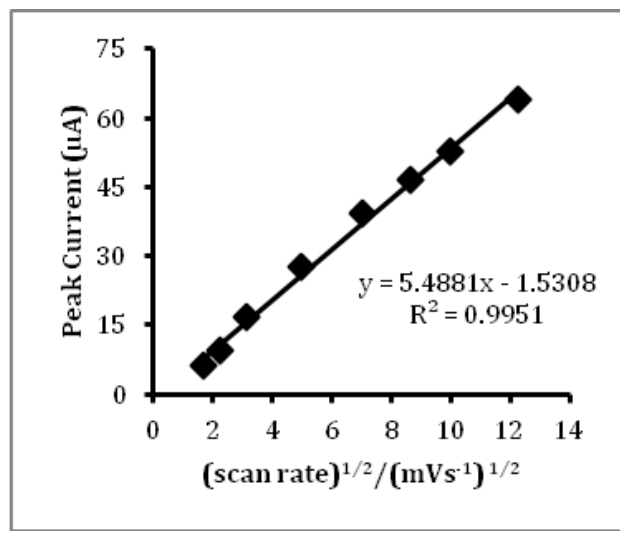

Figure 4. Dependence of scan rate on peak current of $1.0 \times 10^{-4} \mathrm{~mol} \mathrm{~L}^{-1}$ VAN oxidation at Au-MWCNT/GCE in 0.1 M pH 7.15 PBS.

\subsection{DPV Determination of VAN}

To evaluate linear range, LOD, and sensitivity of the Au-MWCNT/GCE, DPV studies were carried out for different concentrations of VAN. Figure 5 depicts the DPV curves of Au-MWCNT/GCE in $\mathrm{N}_{2}$ saturated $\mathrm{pH} \quad 7.15$ PBS containing different concentration of VAN ranging from $7.0 \times 10^{-8} \mathrm{~mol} \mathrm{~L}^{-1}$ to $7.5 \times 10^{-5}$. The two linear calibration curves were obtained in the region of $7.0 \times 10^{-8}-6.5 \times 10^{-6} \mathrm{~mol} \mathrm{~L}^{-}$ 1 and $7.0 \times 10^{-6}-7.5 \times 10^{-5} \mathrm{~mol} \mathrm{~L}^{-1}$. The linear regression equation for lower concentration was obtained as $i_{p}(\mu \mathrm{A})=$ $1.2605 \mathrm{C}$ van $\left(\mu \mathrm{mol} \mathrm{L} \mathrm{L}^{-1}\right)+0.4525$, with correlation coefficient $\mathrm{R}=0.9974$. The linear regression equation for upper concentration was obtained as $i_{p}(\mu \mathrm{A})=$ $0.2463 \mathrm{C}$ van $\left(\mu \mathrm{mol} \mathrm{L}^{-1}\right) 7.9892$, with correlation coefficient $\mathrm{R}=0.9956$. The limit of detection (LOD) was calculated using the equation $\mathrm{LOD}=3.3 \sigma / \mathrm{m}$, where the $\sigma$ is the standard deviation of the response for blank solution, $\mathrm{m}$ is the slope of the calibration graph. The LOD value of VAN on Au-MWCNT/GCE was calculated as $3.8 \times 10^{-8} \mathrm{~mol} \mathrm{~L}^{-1}$. 

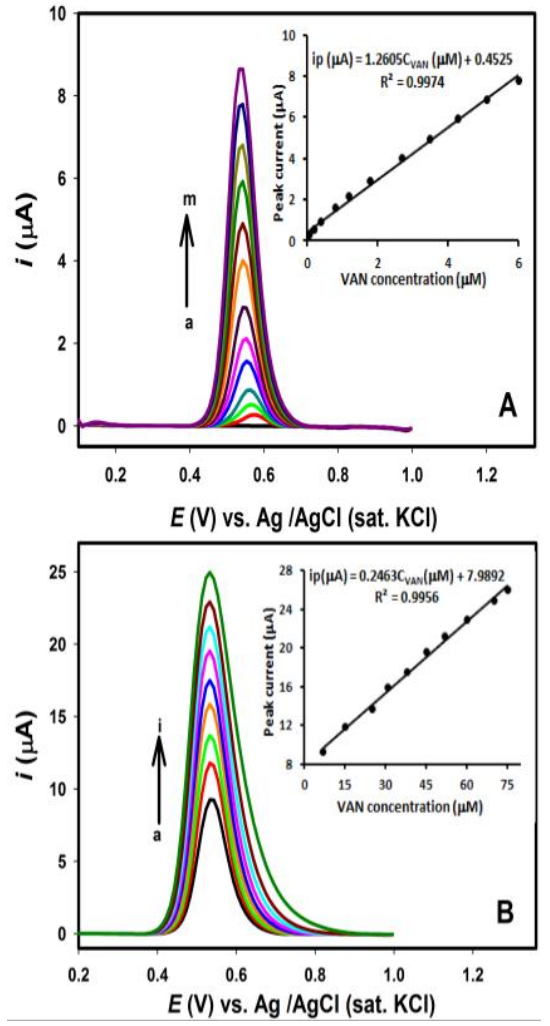

Figure 5. DPVs of Au-MWCNT/GCE in different concentrations of vanillin solutions in $\mathrm{pH} 7.15$ buffer solution. (A) a-m: blank solution and $7.0 \times 10^{-8}-6.5 \times 10^{-6} \mathrm{~mol} \mathrm{~L}^{-1}$ inset: calibration curve for lower concentrations of VAN (B) a-i: $7.0 \times 10^{-6}$ $7.5 \times 10^{-5} \mathrm{~mol} \mathrm{~L}^{-1}$ inset: calibration curve.

\subsection{Stability, Repeatability and Reproducibility Study}

The repeatability of the modified electrode was also evaluated by DPV using the same electrode, while the ten measurements of $5.0 \times 10^{-6} \mathrm{~mol} \mathrm{~L}^{-1} \mathrm{VAN}$ yielded a RSD of $2 \%$. The investigation of reproducibility was evaluated by comparing the DPV responses of ten AuMWCNT/GCEs prepared under the same conditions. The RSD for the resulting signals of $5.0 \times 10^{-6} \mathrm{~mol} \mathrm{~L}^{-1}$ VAN was $3.8 \%$. Additionally, the stability of AuMWCNT/GCE was also studied. The peak current retained $96 \%$ of its original when the modified electrode was stored in 0.1 M PBS at room temperature for 10 days.

\subsection{Interference study}

The influence of potentially interfering compounds on the determination of vanillin was studied by DPV under the optimum conditions.

The interfering organic and inorganic compounds were chosen from the group of substances generally coexisted with vanillin in food products. The tolerance limit was defined as the maximum concentration of the interfering compound that caused an error of less than $5 \%$ for the determination of $5.0 \times$ $10^{-6} \mathrm{~mol} \mathrm{~L}^{-1}$ vanillin. It was observed that the 1000 fold of glucose, sucrose, benzoic acid, caffeic acid, tartaric acid, citric acid, oxalic acid $\mathrm{Fe}^{3+}, \mathrm{Al}^{3+}, \mathrm{Zn}^{2+}, \mathrm{Mg}^{2+}, \mathrm{Pb}^{2+}, \mathrm{K}^{+}$ $\mathrm{Na}^{+}, \mathrm{SO}_{4}^{2-} \mathrm{Cl}^{-}$, and $\mathrm{NO}_{3}^{-}$showed no obvious interference effect to VAN determination.

\subsection{Analysis of Real Example}

To investigate the performance of $\mathrm{Au}$ MWCNT/GCE by practical analytical applications, VAN determination was carried out in ice cream and milk powder. The samples were prepared regarding to section $2.3 .1 .0 \mathrm{~mL}$ of each pre-treated sample solution was transferred to a voltammetric cell containing $\quad 10.0 \mathrm{~mL}$ supporting electrolyte and analyzed in the same day. The content of VAN was determined by standard addition method and results were listed in Table 1 . The amount of VAN was calculated as $0.78 \mathrm{mg} / \mathrm{g}$ and $15.96 \mu \mathrm{g} / \mathrm{g}$ for ice cream and milk powder, respectively. The recovery experiments were also performed that were in the range of $92.81-103.94 \%$. These results indicated that the modified electrode has good analytical performance and it can be accurately used for the VAN determination in commercial food samples. 
Tablo 1. VAN Determination on Au-MWCNT/GCE in different food samples ( $\mathrm{n}=3)$

\begin{tabular}{ccccc}
\hline Samples & $\begin{array}{c}\text { Added } \\
\left(\mu \mathrm{mol} \mathrm{L}^{-1}\right)\end{array}$ & $\begin{array}{c}\text { Found } \\
\left(\mu \mathrm{mol} \mathrm{L}^{-1}\right)\end{array}$ & $\begin{array}{c}\text { Recovery } \\
(\%)\end{array}$ & $\begin{array}{c}\text { RSD } \\
(\%)\end{array}$ \\
Ice cream & - & 5.2 & - & 3.1 \\
& 8.0 & 13.5 & 102.27 & 2.5 \\
& 10.0 & 15.8 & 103.94 & 3.4 \\
Milk powder & 15.0 & 20.1 & 99.50 & 4.0 \\
& - & 2.1 & - & 2.2 \\
& 4.0 & 5.9 & 96.72 & 3.6 \\
& 8.0 & 12.9 & 92.81 & 4.1 \\
& 15.0 & 16.8 & 98.24 & 3.7 \\
\hline
\end{tabular}

\section{Discussion and Conclusion}

In this paper, gold nanoparticles modified glassy carbon electrode was prepared by the electrochemical method. The modified electrode shows improved electrocatalytic activity towards the oxidation of VAN due to the synergistic effect of carbon nanotubes and metal nanoparticles that have increasing electronic conductivity and effective surface area. The developed electrode can be easily fabricated and has a high reproducibility, repeatability and long-term stability. The scanning electron microscopy images confirmed the morphological difference of surface before and after gold nanoparticles deposition on MWCNT/GCE. The differential pulse voltammograms showed that under optimized conditions, the peak currents increased linearly within the two linear ranges. These ranges found as $7.0 \times 10^{-8}-6.5 \times 10^{-6}$ mol $\mathrm{L}^{-1}$ and $7.0 \times 10^{-6}-7.5 \times 10^{-5} \mathrm{~mol} \mathrm{~L}^{-1}$. The detection limit was also calculated as $3.8 \times 10^{-8} \mathrm{~mol} \mathrm{~L}^{-1}$. In conclusion, the prepared modified electrode can be successively used for the voltammetric determination of vanillin in synthetic and real sample analysis with excellent sensitivity and anti-fouling properties.

\section{References}

[1] Sivakumar, M., Sakthivel, M., Chen, Shen-M. 2017. Simple synthesis of cobalt sulfide nanorods for efficient electrocatalytic oxidation of vanillin in food samples, Journal of Colloid and Interface Science, Vol. 490, p. 719-726. DOI: 10.1016/j.jcis.2016.11.094

[2] Walton, N.J., Mayer, M.J., Narbad, A. 2003. Vanillin, Phytochemistry, Vol. 63, p. 505-515. DOI: 10.1016/S0031-9422(03)001493.

[3] Sinha, A.K., Sharma, U.K., Sharma N. 2008. A comprehensive review on vanilla flavor: Extraction, isolation and quantification of vanillin and others constituents, International Journal of Food Sciences and Nutrition, Vol. 59, p. 299-326.

DOI: 10.1080/09687630701539350

[4] Luo, S., Liu, Y. 2012. Poly(acid chrome blue K) modified glassy carbon electrode for the determination of vanillin, International Journal of Electrochemical Science, Vol. 7, p. 6396-6405.

[5] Hardcastle, J.L., Paterson, C.J., Compton, R.G. 2001. Biphasic Sonoelectroanalysis:

Simultaneous Extraction from,and Determination of Vanillin in Food 
Flavoring, Electroanalysis, Vol. 13, p. 899-905.

[6] Jiang, L., Ding, Y., Jiang, F., Li, L., Mo F. 2014. Electrodeposited nitrogen-doped graphene/carbon nanotubes nanocomposite as enhancer for simultaneous and sensitive voltammetric determination of caffeine and vanillin, Analytica Chimica Acta, Vol. 833, p. 22-28. DOI: 10.1016/j.aca.2014.05.010.

[7] Huang, L., Hou, K., Jia, X., Pan, H., Du, M. 2014. Preparation of novel silver nanoplates/graphene composite and their application in vanillin electrochemical detection, Materials Science and Engineering: C, Vol. 38, p. 39-45. DOI: 10.1016/j.msec.2014.01.037.

[8] Shen, Y., Han, C., Liu B., Lin, Z., Zhou, X., Wang, C., Zhu Z. 2014. Determination of vanillin, ethyl vanillin, and coumarin in infant formula by liquid chromatography-quadrupole linear ion trap mass spectrometry, Journal of Dairy Science, Vol. 97, p. 679-686. DOI: 10.3168/jds.20137308.

[9] Ohashi, M., Omae, H., Hashida, M., Sowa, Y., Imai S. 2007. Determination of vanillin and related flavor compounds in cocoa drink by capillary electrophoresis, Journal of Chromatography A, Vol. 1138, p. 262-267. DOI: 10.1016/j.chroma.2006.10.031.

[10] Turkia, H., Sirén, H., Penttilä M., Pitkänen J.P. 2013. Capillary electrophoresis for the monitoring of phenolic compounds in bioprocesses, Journal of Chromatography A, Vol. 1278, p. $175-180$.

DOI: 10.1016/j.chroma.2013.01.004.

[11] Timotheou-Potamia, M., Calokerinos A.C. 2007. Chemiluminometric determination of vanillin in commercial vanillin products, Talanta, Vol. 71, p. 208-212. DOI: 10.1016/j.talanta.2006.03.046.

[12] Duan, H., Li, X., Li, L., Wang, X., Feng, J., Sun, M., Luo C. 2014. A novel chemiluminescence sensor for determination of vanillin with magnetite-graphene oxide molecularly imprinted polymers, Analytical Methods, Vol. 6, p. 8706-8712.

DOI: 10.1039/C4AY01275E.

[13] Waliszewski, K.N., Pardio, V.T., Ovando S.L. 2007. A simple and rapid HPLC technique for vanillin determination in alcohol extract, Food Chemistry,Vol. 101, p. 10591062.

DOI: 10.1016/j.foodchem.2006.03.004.

[14] de Jager, L.S., Perfetti, G.A., Diachenko, G.W. 2007. Determination of coumarin, vanillin, and ethyl vanillin in vanilla extract products: liquid chromatography mass spectrometry method development and validation studies. Journal of Chromatography A, Vol. 1145, p. 83-88. DOI: 10.1016/j.chroma.2007.01.039.

[15] Sinha, A.K., Sharma, U.K., Sharma, N. 2008. A comprehensive review on vanilla flavor: extraction, isolation and quantification of vanillin and others constituents, International Journal of Food Sciences and Nutrition, Vol. 59, p. 299-326. DOI: 10.1080/09687630701539350.

[16] Silva, T.R., Brondani, D., Zapp, E., Vieira, I.C. 2015. Electrochemical sensor based on gold nanoparticles stabilized in poly(allylamine hydrochloride) fordetermination of vanillin, Electroanalysis, Vol. 27, p. 465472. DOI: 10.1002/elan.201400517. 
[17] Yardım, Y., Gülcan, M., Sentürk, Z. 2013. Determination of vanillin in commercial food product by adsorptive stripping voltammetry using a boron-doped diamond electrode, Food Chemistry, Vol. 141 , p. 1821-1827. DOI: 10.1016/j.foodchem.2013.04.085.

[18] Yardım, Y., Gülcan, M., Şentürk Z. 2013. Determination of vanillin in commercial food product by adsorptive stripping voltammetry using a boron-doped diamond electrode, Food Chemistry, Vol. 141, p. 1821-182. DOI: 10.1016/j.foodchem.2013.04.085.

[19] Ali, H.S., Abdullah, A.A., Pınar, P.T., Yardım, Y., Şentürk Z. 2017. Simultaneous voltammetric determination of vanillin and caffeine in food products using an anodically pretreated borondoped diamond electrode: Its comparison with HPLC-DAD, Talanta, Vol. 170, P. 384-391. DOI: 10.1016/j.talanta.2017.04.037.

[20] Chethana, B.K., Basavanna, S., Naik, Y.A. 2012. Determination of vanillin in real samples using lysine modified carbon paste electrode, Journal of Chemical and Pharmaceutical Research, Vol. 4, p. 538-545.

[21] Peng, J., Hou, C., Hu, X. 2012. A graphene-based electrochemical sensor for sensitive detection of vanillin, International Journal of Electrochemical Science, Vol. 7, p. 1724-1733.

[22] Li, J., Feng, H., Li, J., Jiang, J., Feng, Y., He, L., Qian,D. 2015. Bimetallic Ag-Pd nanoparticlesdecorated graphene oxide: a fascinating three-dimensional nanohybrid as an efficient electrochemical sensing platform for vanillin determination, Electrochimica Acta, Vol. 176, p. 827-835. DOI: 10.1016/j.electacta.2015.07.091.
[23] Ulubay, Ş., Dursun, Z. 2010. Cu nanoparticles incorporated polypyrrole modified GCE for sensitive simultaneous determination of dopamine and uric acid, Talanta, Vol. 80, p. 1461-1466. DOI: 10.1016/j.talanta.2009.09.054.

[24] Development of pulsed deposited manganese and molybdenum oxide surfaces decorated with platinum nanoparticles and their catalytic application for formaldehyde oxidation Ozdokur, K.V., Tatlı, A.Y., Yılmaz, B., Koçak, S., Ertaş F.N. 2016. International Journal of Hydrogen Energy, Vol. 41, p. 5927 $-5933$. DOI: 10.1016/j.ijhydene.2016.02.127.

[25] Koçak, S., Aslışen B. 2014. Hydrazine oxidation at gold nanoparticles and poly(bromocresol purple) carbon nanotube modified glassy carbon electrode, Sensors and Actuators B, Vol. 196, p. 610-618. DOI: .org/10.1016/j.snb.2014.02.061.

[26] Cittan, M., Koçak, S., Çelik, A., Dost K. 2016, Determination of oleuropein using multiwalled carbon nanotube modified glassy carbon electrode by adsorptive stripping square wave voltammetry, Talanta, Vol. 159 p. 148-154. DOI: 10.1016/j.talanta.2016.06.021.

[27] Bakır, C..C., Şahin, N., Polat, R., Dursun Z. 2011. Electrocatalytic reduction of oxygen on bimetallic copper-gold nanoparticlesmultiwalled carbon nanotube modified glassy carbon electrode in alkaline solution, Journal of Electroanalytical Chemistry, Vol. 662 p. 275-280.

[28] Ertek, B., Dilgin, Y. 2016. Photoamperometric flow injection analysis of glucose based on dehydrogenase modified quantum 
$\begin{array}{ll}\text { dots-carbon } & \text { nanotube } \\ \text { nanocomposite } & \text { electrode, }\end{array}$ Bioelectrochemistry, Vol. 112, p. 138-144.

DOI:

10.1016/j.bioelechem.2016.02.00

8.

[29] Ayan, E.M., Karabiberoğlu, Ș.U., Dursun, Z. 2013. Electrochemistry of 2,6-diaminopurine on multiwall carbon nanotube modified glassy carbon electrode, Turkish Journal of Chemistry, Vol.37, p. 325-334. DOI: 10.3906/kim-1111-4. 